\title{
MODEL PEMBELAJARAN TERPADU DAN PENDEKATAN SAINTIFIK DALAM CREATIVITY BUILDING FOR STUDENTS PADA SEKOLAH DASAR NEGERI (SDN) DI KOTA BANDUNG
}

Hj. UUM Murfiah, M.Pd

Dosen Universitas Pasundan

\begin{abstract}
ABSTRAK
Hasil studi internasional untuk reading and literacy (PIRLS) yang ditunjukkan untuk kelas IV SD juga menunjukkan hasil yang belum menggembirakan, dalam hal membaca, lebih dari 95\% peserta didik Indonesia di SD kelas IV juga hanya mampu mencapai level menengah, sementara lebih dari 50\% siswa taiwan mampu mencapai level tinggi dan advance. Hal ini juga menunjukkan bahwa apa yang diajarkan Indonesia berbeda dengan apa yang diujikan dan distandarkan pada tingkat internasional (Kemendikbud, 2013:77).

Penelitian ini menggunakan metode penelitian kuantitatif dengan populasi seluruh SD Negeri di Kota Bandung sejumlah adalah 644 sekolah dasar negeri (SDN) dan11497 guru serta terdapat 226796 peserta didik dengan peserta laki-laki adalah 116026 dan peserta didik perempuan adalah 110772 dengan rasio guru dan peserta adalah 1:20, artinya satu orang guru mengajar pada 20 orang peserta didik. Memiliki 30 kecamatan dan 151 kelurahan/desa (BPS Jabar 2012). Sedangkan sampel yang digunakan adalah 50 sekolah dasar negeri (SDN) di Kota Bandung dengan menarik sampel berdasarkan area sampling berdasarkan letak geografis SD Negeri di Kota Bandung tersebut, yang terdiri dari tiga kategori, yaitu: yaitu: (1) sekolah dasar negeri yang mudah dijangkau peneliti, (2) sekolah dasar negeri yang sulit dijangkau peneliti, dan (3) sekolah dasar negeri yang tidak mudah dan tidak sulit (tengahtengah) untuk dijangkau peneliti. Ketiga kategori diambil sebagai sampel terdiri dari 100 responden dengan menggunakan rumus Yamato atau Slovin, setiap sekolah terdapat 2-3 responden yang diambil secara acak.

Penelitian ini merupakan upaya untuk mengembangkan kreatifitas peserta didik melalui model pembelajaran terpadu dan pendekatan saintifik, dimana model pembelajaran terpadu memberikan rangsangan kepada peserta didik agar dapat mengembangkan bahanbahan materi yang ada sebagai pembangunan kreatifitasnya, sementara pendekatan saintifik merupakan upaya pembelajaran yang mengedepankan dengan menggunakan $5 \mathrm{~m}$ (melihat, menanya, mencoba, menalar dan mengkomunikasikan). Pembangunan kreatifitas peserta didik tentunya melihat dengan bagaimana kreatifitas guru-guru yang memberikan materi pengajarannya kepada peserta didik tersebut. Jurnal yang menjadi target adalah Jurnal terakreditasi nasional yaitu Jurnal Sekolah Dasar Program studi PGSD PP1 Jurusan Kependidikan Sekolah Dasar dan Prasekolah (KSDP) FIP Universitas Negeri Malang, jurnal internasional Published by Canadian Center of Science and Edudcation, buku ajar ber ISBN anggota IKAPI dan Hak Kekayaan Intelektual (HKI) dalam bentuk hak cipta.
\end{abstract}

Kata Kunci: Pembelajaran Terpadu, pendekatan Saintifik dan Creativity Building. 


\section{PENDAHULUAN}

\section{A. LATAR BELAKANG MASALAH}

Pendidikan dasar merupakan fondasi yang amat mendasar dalam menanamkan nilai-nilai pendidikan, sikap, pengetahuan dan keterampilan bagi anak. Pada usia pendidikan dasar inilah pembelajaran harus lebih kreatif dan inovatif. Namun realitas di lapangan tidak jarang guru sekolah dasar menerapkan pembelajaran yang konvensional sehingga anak tidak semangat, jenuh, sehingga suasana pembelajaran tidak kondusif untuk mengembangkan potensi anak. Dengan pembelajaran yang masih cenderung konvensional ini mengakibatkan kreativitas anak tidak berkembang.

Fenomena tersebut penting untuk diteliti dengan tujuan agar pembelajaran di sekolah dasar lebih berkualitassehingga potensi anak berkembang sesuai dengan usia perkembangannya. Pendidikan dasar yang berkualitas penting mendapat perhatian, karena masa inilah yang akan mempengaruhi anak pada masa-masa berikutnya. Jika pendidikan dasar berkualitas dapat diraih anak, maka pendidikan selanjutnya akan lebih baik lagi.

Susanto (2015:91) menyatakan bahwa rendahnya minat baca menjadi problem utama yang dihadapi bangsa kita. Hal ini terlihat dari tertinggalnya kualitas pendidikan kita oleh negara-negara tetangga, dan menunjukkan kualitas pendidikan kita lebih rendah dibanding mereka. Salah satunya adalah akibat dari kebiasaan membaca yang sangat rendah dan ini berakibat fatal kepada kualitas SDM-nya sendiri, sebab kepintaran daya nalar seseorang salah satu kunci utamanya ditentukan oleh frekuensi dan banyaknya buku yang dibaca (kultur membaca).

Bank Dunia melaporkan tentang hasil pengukuran indikator mutu secara secara kuantitatif pada sekolah dasar (SD) di beberapa negara Asia. Hasilnya menunjukkan bahwa hasil tes membaca murid kelas IV SD, Indonesia berada pada tingkat terendah di Asia, berada di bawah Hong Kong 75,5\%, Singapura 74\%, Thailand $65,1 \%$, Filipina $52,6 \%$, dan Indonesia $51,7 \%$. Dari hasil penelitian ini menunjukkan disebutkan pula bahwa para siswa di Indonesia hanya mampu menguasai $30 \%$ dari materi bacaan yang dibacanya. Siswa Indonesia mengalami kesulitan menjawab soal-soal bentuk uraian yang memerlukan penalaran. Direktorat Pendidikan TK dan SD Departemen Pendidikan Nasional tahun 2000/2001 melaporkan bahwa rata-rata daya serap kurikulum secara nasional masih rendah, yaitu 5,1 untuk lima mata pelajaran (Majid, 2014:5)

Salah satu upaya mengatasi permasalahan ini, guru harus mampu merancang model pembelajaran yang 
bermakna bagi siswa. Untuk itu, guru harus kreatif dalam mendesain model pembelajaran yang memungkinkan siswa dapat berpartisipasi, aktif, kreatif terhadap materi yang diajarkan. Dengan cara demikian, diharapkan siswa dapat memahami materi yang diberikan dan mencapai pembelajaran yang bermakna (Susanto, 2015:93).

Sani (2014:7) menyatakan bahwa pada saat ini kompetensi untuk hidup layak bergantung pada kreativitas dan kemampuan melakukan inovasi. Kondisi ini menyebabkan negara yang memiliki sumber daya manusia yang unggul akan lebih maju daripada negara dengan sumber daya alam yang banyak, namun tidak memiliki sumber daya alam yang handal. Misalnya, Singapura yang tidak memiliki sumber minyak ternyata memiliki kilang pengolah minyak, sedangkan Indonesia yang memiliki sumber minyak bumi ternyata lebih banyak mengekspor minyak mentah ke negara lain. Contoh lain, Malaysia mampu mengolah minyak sawi mentah (CPO) untuk menghasilkan puluhan produk, sedangkan Indonesia hanya mampu menghasilkan beberapa produk saja.

Kemendikbud (2013:75) berdasarkan analisis hasil PISA 2009 ditemukan bahwa dari enam level kemampuan yang dirumuskan dalam studi PISA, hampir semua peserta didik Indonesia hanya mampu menguasai pelajaran sampai level tiga saja, sementara negara lain yang terlibat dalam studi ini banyak yang mencapai level empat, lima, dan enam. Dengan keyakinan bahwa semua manusia diciptakan sama, interpretasi yang dapat ditimbulkan dari hasil hasil studi ini, hanya satu yaitu yang kita ajarkan berbeda dengan tuntutan zaman.

Hasil studi internasional untuk reading and literacy (PIRLS) yang ditunjukkan untuk kelas IV SD juga menunjukkan hasil yang belum menggembirakan, dalam hal membaca, lebih dari $95 \%$ peserta didik Indonesia di SD kelas IV juga hanya mampu mencapai level menengah, sementara lebih dari 50\% siswa taiwan mampu mencapai level tinggi dan advance. Hal ini juga menunjukkan bahwa apa yang diajarkan Indonesia berbeda dengan apa yang diujikan dan distandarkan pada tingkat internasional (Kemendikbud, 2013:77).

Pembelajaran terpadu merupakan pembelajaran yang mengkaitkan berbagai macam dimensi keilmuan menjadi sebuah tema yang mudah dipahami oleh peserta didik. Sejalan dengan pemikiran Hosnan (2014:19) menyatakan bahwa dalam praktiknya, guru dalam proses kegiatan pembelajaran untuk mencapai hasil yang diharapkan melalui empat azas, yaitu logika, praktika, etika dan estetika.

1. Logika, yaitu keterampilan berpikir dan berpikir logis, dilatihkan melalui berbagai mata pelajaran 
2. Praktekka, yaitu hal-hal yang bersifat praktik, harus dipraktikkan, tidak hanya dipikirkan, diangankan atau dipelajari secara teori. Terutaman, olah raga, kesenian, serta pelajaran lain yang mengandung unsur praktik.

3. Etika, yaitu budi pekerti, sopan santun, adat dan nilai-nilai setempat, yang semua itu dapat dilatih melalui tata tertib sekolah, peraturan yang disepakati bersama, pembiasaan dan contoh-contoh konkret. Ada teguran dan sanksi jika dilanggar, serta ada pujian jika dilaksanakan dengan baik.

4. Estetika, yaitu tentang keindahan, kebersihan dan kerapian, perlu pembiasaan sejak dini di sekolah. Baik melalui tata tertib sekolah, pekerjaan tangan dan kesenian yang memupuk rasa kehalusan budi, serta melalui pelajaranpelajaran yang lain.

Pentingnya pendidikan yang mengarahkan pada kreatifitas, tentunya sebagai upaya dalam meminimalisir berbagai kenakalan remaja, yang sumber utamanya adalah cara seorang anak mendapatkan pendidikan ketika sekolah dasar (SD). Pembelajaran terpadu lebih mengedepankan pada konsep pengajaran berbasis tema. Sundayana (2014:11) menyatakan bahwa pengajaran berbasis tema memiliki kelebihan sebagai berikut:

1. Kontak, memberikan keleluasaan baik pada guru maupun peserta didik untuk mengembangkan keluasan dan kedalaman kurikulum serta memberikan kesempatan kepada peserta didik untuk lebih terlibat dalam pembelajaran.

2. Koherensi, memberikan peluang terwujudnya pengalaman belajar yang melibatkan aspek-aspek kognitif, psikomotor, maupun afektif atau mulitiple intelligence.

3. Koneksi, membangun kemungkinan berbagai hubungan antar pengetahuan atau disipilin (interdiscipliner) atau di dalam pengetahuan itu sendiri.

4. Konteks, memberi peluang terwujudnya pembelajaran yang kontekstual, adanya keterkaitan antara apa yang dipelajari peserta didik dengan apa yang dialami dan diketahui oleh mereka dalam kehidupannya.

5. Kerja sama, membangun proses pembelajaran berdasarkan kerja sama antara guru dan peserta didik, serta peserta didik dengan peserta didik hingga terbangun komunitas warga belajar (comunity of learner) di dalam kelas.

Pendekatan saintifik dalam pembelajaran memiliki proses pembelajaran antara lain sebagai berikut yaitu: (1) mengamati, (2) menanya, (3) mengumpulkan informasi, (4) menalar dan mengkomunikasikan. Namun, tahapan pembelajaran saintifik tidak harus dilakukan dengan prosedur yang kaku, bahkan dapat disesuaikan dengan pengetahuan yang 
hendak dipelajari. Pada suatu tahapan mungkin dapat dilakukan observasi atau pengamatan terlebih dahulu sebelum melakukan pertanyaan, namun pada pembelajaran lain siswa boleh mengajukan pertanyaan terlebih dahulu sebelum melakukan pertanyaan (Sani, 2014:54).

Peneliti mencoba melakukan pendekatan pembelajaran terpadu dengan aspek kontak, koherensi, koneksi dan konteks yang menghasilkan siswa-siswa yang memiliki kreatifitas melalui aspekaspek logika, praktekka, etika dan estetika, dan pendekatan saintifik dalam aspek mengamati, menanya, mengumpulkan informasi, menalar dan mengkomunikasikan dalam pembentukan kreatifitas. Oleh karena itu, penelitian ini akan meneliti model pembelajaran terpadu (integrated) dan pendekatan saintifik dalam creativity building for students pada SD Negeri Kota Bandung.

\section{B. TUJUAN PENELITIAN}

\section{Tujuan Khusus}

Secara khusus penelitian bertujuan mengungkapkan sebagai berikut:

a) Gambaran pembelajaran model pembelajaran pada SD Negeri Kota Bandung.

b) Gambaran pendekatan saintifikpada SD Negeri Kota Bandung

c) Gambaran creativity building for students padaSD Negeri Kota Bandung. d) Gambaranpembelajaran model terpadu (integrated) dan pendekatan saintifik dalam creativity building for students pada SD Negeri Kota Bandung.

\section{URGENSI PENELITIAN}

Urgensi penelitian dibedakan menjadi dua, yaitu:

\section{Secara Teoritis}

Secara teoritis penelitian ini memiliki urgensi, sebagai berikut:

a) Studi lanjutan yang relevan dan bahan kajian ke arah model pembelajaran terpadu (integrated) dan pendekatan saintifik yang mendekati pertimbanganpertimbangan kontekstual dan konseptual.

b) Studi lanjutan yang relevan dan bahan kajian ke arah creativity building for students yang mendekati pertimbanganpertimbangan kontekstual dan konseptual.

c) Studi lanjutan yang relevan dan bahan kajian ke arah model pembelajaran terpadu (integrated)dan pendekatan saintifik dalam bahan kajian ke arah creativity building for students yang mendekati pertimbangan-pertimbangan kontekstual dan konseptual.

\section{Secara Praktis}

Secara praktis urgensi penelitian ini sebagai berikut:

a) Sebagai masukan bagi SD Negeri di Kota Bandung secara operasional dalam merumuskan model pembelajaran terpadu (integrated) dan pendekatan saintifik dalam creativity building for students. 
b) Sebagai masukan bagi pimpinan di SD Negeri Kota Bandung mengenai pembelajaran terpadu (integrated) dan pendekatan saintifik dalamcreativity building for students.

c) Sebagai bahan perbandingan bagi pimpinan Dinas Pendidikan di Kota Bandung mengenai pembelajaran terpadu (integrated) dan pendekatan saintifikdalam creativity building for students

d) Sebagai masukan bagi peneliti, sebagai temuan awal untuk melakukan penelitian lanjut tentang pembelajaran terpadu (integrated) dan pendekatan saintifikdalam creativity building for students.

Penelitian menargetkan temuan model pembelajaran terpadu dan pendekatan saintifik dalam creativity building for studenstyang sesuai dengan model pendidikan pada tingkat sekolah dasar di Kota Bandung. Sedangkan, rencana target capaian tahunan dalam penelitian ini tahun pertama, yaitu: publikasi ilmiah dalam jurnal internasional Published by Canadian Center of Science and Education Jurnal yang menjadi target adalah Jurnal terakreditasi nasional yaitu Jurnal Sekolah Dasar Program studi PGSD PP1 Jurusan Kependidikan Sekolah Dasar dan Prasekolah (KSDP) FIP Universitas Negeri Malang, jurnal internasional Published by Canadian Center of Science and Edudcation, buku ajar ber
ISBN dan Hak Kekayaan Intelektual (HKI) dalam bentuk hak cipta.

\section{TINJAUAN PUSTAKA}

\section{A. Pembelajaran Terpadu (Integrated} Learning)

Konsep utama integrated learning adalah bagaimana siswa belajar secara alamiah yang meliputi proses dalam mengembangkan kemampuan berpikir dan dengan memusatkan analisis proses berpikir serta perincian ketetapan dari petunjuk kurikulum untuk memajukan dan mempertinggi pikiran dan pemahaman anak. Materi integrated learning selain diambil dari kurikulum juga mengambil peristiwa otentik bagi siswa. Siswa dilibatkan secara langsung dalam mengeksplorasi peristiwa atau topik, siswa tidak hanya mempelajari isi saja melainkan juga proses yang berhubungan dengan kurikulum dalam waktu yang sama (Isjoni, 2007:137).

$$
\text { Fogarty (Isjoni, }
$$

menyatakan bahwa pembelajaran terpadu (integrated learning) sebagai konsep dapat pula dikatakan sebagai pendekatan belajar mengajar yang melibatkan berbagai bidang studi untuk memberikan pengalaman yang bermakna bagi peserta didik. Dikatakan bermakna karena dalam pembelajaran terpadu peserta didik akan memahami konsep-konsep yang mereka pelajari melalui pengalaman langsung dan 
menghubungkannya dengan konsep lain yang sudah mereka miliki.

Fokus pembelajaran bermakna sesuai dengan pandangan bahwa belajar adalah mengkonstruksi pengetahuan, yang di dalamnya siswa memahami pengalamanpengalaman mereka. Pembelajaran bermakna dipandang sebagai tujuan pendidikan yang penting yang mensyaratkan pembelajaran tidak sekedar menyampaikan pengetahuan faktual dan juga mensyaratkan pertanyaanpertanyaan asesmen yang menuntut siswa bukan sekedar mengingat atau mengenali pengetahuan faktual (Anderson dan Krathwol, 2010:98).

Sejalan dengan pandangan ini, Ausabel (Sundayana, 2014:9) melalui teori pembelajaran bermakna bahwa learning takes place in the human organism through a meaningful process of relating new events or items to already existing cognitive consepts or propositions. Teori ini menunjukkan bahwa pembelajaran bagi peserta didik akan bermakna bila apa yang dipelajari oleh mereka berhubungan dengan apa yang diketahui dan dialaminya.

Isjoni (2007:135) menyatakan bahwa karakteristik integrated learning yang dimaksud meliputi, sebagai berikut:

1. Holistik, suatu gejala atau peristiwa yang menjadi pusat perhatian dalam pembelajaran terpadu diamati dan dikaji dari berbagai bidang studi sekaligus, tidak dari sudut pandang yang terkotak-kotak.
Pembelajaran memungkinkan siswa untuk memahami suatu fenomena dari segala sisi yang pada gilirannya siswa menjadi lebih arif dan bijak di dalam menyikapi atau menghadapi kejadian yang dihadapinya.

2. Bermakna, pengkajian fenomena dari berbagai aspek seperti di atas memungkinkan terbentuknya semacam jalinan antar skemata yang dimiliki siswa sehingga hasil belajar akan lebih bermakna dan nyata dari berbagai konsep yang dipelajari. Kegiatan belajar mengajar yang lebih fungsional memungkinkan siswa dapat menerapkan hasil belajarnya untuk memecahkan masalah-masalah di dalam kehidupannya.

3. Otentik, kegiatan pembelajaran yang dilaksanakan secara langsung memungkinkan anak memahami hasil belajarnya sendiri dari interrelasinya dengan fakta dan peristiwa, bukan sekedar hasil pemberitahuan guru, informasi pengetahuan yang diperoleh sifatnya lebih otenik.

4. Aktif, integrated learning pada dasarnya dikembangkan dengan berdasarkan kepada pendekatan discovery-inquiry. Siswa perlu terlibat secara aktif dalam proses pembelajaran mulai dari perencanaan, pelaksanaan, hingga evaluasinya.

\section{B. PENDEKATAN SAINTIFIK}


Hosnan (2014:35) menyatakan bahwa pendekatan saintifik sangat relevan dengan tiga teori belajar, yaitu teori Brunner, teori Piaget, dan teori Vigotsky.

Teori Bruner disebut juga teori belajar penemuan. Ada empat hal pokok berkaitan dengan teori belajar Brunner, yaitu: (1) individu hanya belajar dan mengembangkan pikirannya apabila ia menggunakan pikirannya, (2) dengan melakukan proses-proses kognitif dalam proses penemuan, siswa akan memperoleh sensasi dan kepuasan intelektual yang merupakan suatu penghargaan intrinsik, (3) satu-satunya cara agar seseorang dapat mempelajari teknik-teknik dalam melakukan penemuan adalah ia memiliki kesempatan untuk melakukan penemuan, (4) dengan melakukan penemuan maka akan memperkuat retensi ingatan (Hosnan, 2014:35).

Bruner (Syah, 2013:110) menyatakan bahwa dalam proses belajar siswa menemouh tiga tahap, yaitu: (1) tahap informasi, seorang siswa yang sedang belajar memperoleh sejumlah keterangan mengenai materi yang sedang dipelajari. Informai itu ada yang baru, menambah, memperhalus, dan memperdalam pengetahuan, (2) tahap transformasi, informasi yang telah diperoleh itu dianalisis, diubah, atau ditransformasikan menjadi bentuk yang abstrak atau konseptual supaya kelak pada gilirannya dapat dimanfaatkan bagi hal-hal yang lebih luas, dan (3) tahap evaluasi, seorang siswa menilai sendiri sampai sejauh mana informasi yang telah ditransformasikan tadi dapat dimanfaatkan untuk memahami gejala atau memecahkan masalah yang dihadapi.

Teori Piaget, menyatakan bahwa belajar berkaitan dengan pembentukan dan perkembangan skema (jamak skemata). Skema adalah struktur mental atau struktur kognitif yang dengannya seseorang secara intelektual beradaptasi dan mengkoordinasi lingkungan sekitarnya. Skema tidak pernah berhenti berubah, skemata seorang anak akan berkembang menjadi skemata orang dewasa. Proses yang menyebabkan terjadinya skemata disebut dengan adaptasi. Proses terbentuknya adaptasi ini dapat dilakukan dengan dua cara, yaitu asimilasi dan akomodasi. Asimilasi merupakan proses kognitif yang dengannya seseorang mengintegrasikan stimulus yang dapat berupa persepsi, konsep, hukum, prinsip ataupun pengalaman baru ke dalam skema yang sudah ada di dalam pikirannya. Akomodasi dapat berupa pembentukan skema baru yang dapat cocok dengan ciri-ciri rangsangan yang ada atau memodifikasi skema yang telah ada sehingga cocok dengan ciri-ciri stimulus yang ada (Hosnan, 2014:35).

Piaget (Aunurrahman, 2012:44) menyatakan bahwa perkembangan intelektual melalui empat tahap, yaitu: (1) tahap sensori motor (0,0-2,0 tahun), pada 
tahap ini anak mengenal lingkungan dengan kemampuan sensorik dan motorik, anak mengenal lingkungan dengan penglihatan, penciuman, pendengaran, perabaan, dan pergerakannya, (2) tahap pra operasional (2,0-7,0 tahun), pada tahap ini anak mengandalkan diri pada persepsi tentang realitas, ia telah mampu menggunakan simbol, bahasa, konsep sederhana, berpartisipasi, membuat gambar, dan menggolong-golongkan, tahap operasional konkret (7,0-11,0 tahun), pada tahap ini anak dapat mengembangkan pikiran logis, ia dapat mengikuti penalaran logis, walau kadang-kadang memecahkan masalah secara trial and error, dan (4) tahap operasional (11,0-ke atas), pada tahap ini operasi formal anak dapat berpikir abstrak seperti pada orang dewasa.

$$
\text { Vygotsky, dalam teorinya }
$$
menyatakan bahwa pembelajaran terjadi apabila peserta didik bekerja atau belajar menangani tugas-tugas yang belum dipelajari namun tugas-tugas itu masih berada dalam jangkauan kemampuan atau tugas itu berada dalam zone of proximal development daerah terletak antara tingkat perkembangan anak saat ini yang didefinisikan sebagai kemampuan pemecahan masalah di bawah bimbingan orang dewasa atau teman sebaya yang lebih mampu (Hosnan, 2014:35).

$$
\text { Hoy dan Miskel }
$$
menyatakan bahwa Vygotskybelieved that knowledge is socially constructted, that is, knowledge is built upon what participants contribute and construct together. Thus development may proceed differently in different cultural contexs. Social interaction, cultural tools, and activity shape individual development and learning.

Konsep ini menjelaskan bahwa Vygotsky percaya dengan pengetahuan merupakan konstruksi sosial, pengetahuan dibangun di atas kontribusi partisipan dan mengkonstruksinya dengan secara bersamasama. Kemudian, pengembangan kemungkinan berjalan berbeda-beda, dalam perbedaan konteks budaya. Interaksi sosial, perangkat budaya, dan keadaan aktivitas pengembangan dan pembelaran individu.

Hosnan (2014:38) menyatakan bahwa pendekatan saintifik mempunyai kriteria proses pembelajaran sebagai berikut:

1. Materi pembelajaran berbasis pada fakta atau fenomena yang dapat dijelaskan dengan logika atau penalaran tertentu.

2. Penjelasan guru, respon siswa, dan interaksi edukatif guru-siswa terbebas dari prasangka yang serta merta.

3. Mendorong dan menginspirasi siswa berpikir secara kritis, analistis, dan tepat dalam mengidentifikasi, memahami, memecahkan masalah dan mengaplikasikan materi pembelajaran.

4. Mendorong dan menginspirasi siswa mampu berpikir hipotetik dalam melihat perbedaan, kesamaan, dan tautan satu sama lainnya dari materi pembelajaran. 
5. Berbasis pada konsep, teori dan fakta empiris yang dapat dipertanggungjawabkan.

6. Tujuan pembelajaran dirumuskan secara sederhana dan jelas, namun menarik sistem penyajiannya.

\section{KREATIVITAS SISWA}

Kreativitas adalah kemampuan guru dalam meninggalkan gagasan, ide-ide, halhal yang dinilai mapan, rutinitas, usang dan beralih untuk menghasilkan atau memunculkan gagasan, ide-ide dan tindakan yang baru dan menarik, apakah itu untuk pemecahan suatu masalah, suatu metode atau alat,suatu objek atau bentuk artistik yang baru yang menuntut adanya daya cipta seorang guru untuk menghasilkan suatu yang baru dalam melaksanakan proses pembelajaran (Hosnan, 2014:19).

Howard (Sani, 2014:14) menyatakan bahwa ada dua jenis pengetahuan yang mungkin diperlukan untuk menghasilkan kreatifitas, yaitu: (1) pengalaman mendalam dan fokus pada suatu kajian tertentu yang membuat seseorang menjadi ahli, dan (2) kemampuan mengombinasikan elemenelemen dengan cara yang baru.

Kreatifitas dapat dikembangkan dalam diri siswa melalui proses belajar yang mencakup: (1) pengembangan imajinasi, (2) menghasilkan sesuatu yang orisinil (asli), (3) meningkatkan produktivitas, penyelesaian masalah, dan (5) menghasilkan sesuatu yang bernilai (Sani, 2014:24).
Ayan (Hosnan,

2014:21)

mengemukakan paling sedikit ada empat dasar pembentuk daya kreatifitas seseorang (disebut CORE), yaitu:

1. Unsur pertama (C-curiosity) mengacu pada makna keingintahuan sebagai dasar untuk menimbulkan kreatif. Rasa ingin tahu mendorong orang untuk menyelidiki sesuatu yang baru, mencari cara untuk mengerjakan sesuatu dengan lebih baik, mengendalikan dorongan mencipta ataupun bereksperimen.

2. Unsur kedua (O-opennes) adalah olah keterbukaan, merupakan dasar vital dalam pengembangan daya kreatif, seseorang tidak akan memiliki daya kreatif apabila hanya mau menerima keyakinan yang sudah baku, sehingga tidak akan merasa tertantang untuk memperluas cakrawala pengetahuan dan wawasannya.

3. Unsur ketiga (R-risk) adalah resiko, yaitu keberanian untuk mengambil resiko terhadap pengadopsian gagasan, ide, ataupun hal-hal baru. Kreatifitas baru muncul apabila terdapat keberanian menanggung resiko dengan penolakan terhadap kemapanan ataupun rutinitas yang dihadapi sehari-hari.

4. Unsur keempat (E-energy) mengacu pada pengertian energi sebagai pendorong kerja dan pemacu hasrat. Tanpa adanya energi mental dan fisik, gagasan ataupun ide-ide kreatif tidak akan berlangsung. Dengan energi yang besar seseorang akan 
bergairah mengerjakan sesuatu dan semakin kreatif.

\section{REFERENSI}

Akdon. (2008). Aplikasi Statistika dan Metode Penelitian untuk Administrasi dan Manajemen. Bandung: Dewa Ruchi.

Anderson W, Lorin, dan Krathwol R, David. (2010). Kerangka Landasan Pembelajaran, Pengajaran dan Asesmen. Yoyakarat: Pustaka Pelajar.

Arikunto, Suharsimi. (2002). Prosedur Penelitian Suatu Pendekatan Praktek. Edisi Revisi. Jakarta: Rineke Cipta.

Aunurrahman. (2012). Belajar dan Pembelajaran. Bandung: Penerbit Alfabeta.

BPS dan Bapeda Jabar. (2012). Jawa Barat dalam Angka Jawa Barat in Figures 2012. Bandung: Bidang Integrasi Pengolahan dan Diseminasi Statistik.

Hoy, K Wayne dan Miskel, G Cecil. (2008). Educational Administration Theory, Research, and practice (Eighth Edition). New York: McGraw-Hill Company.

Isjoni. (2007). Integrated Learning. Pekanbaru: Falah Prodution.

Kemendikbud. (2013). Materi Pelatihan Guru Implementasi Kurikulum 2013. Jakarta: BPSDMPKPMP

Kemendikbud.

Kunandar. (2014). Penilaian Autentik. Penilaian Hasil Belajar Peserta Didik Berdasarkan Kurikulum 2013. Suatu Pendekatan Praktis. Jakarta: Rajawali Pers.
Majid, Abdul. (2014). Pembelajaran Tematik Terpadu. Bandung: PT Remaja Rosdakarya.

Masri, Singarinbum dan Effendi. (2003). Metode Penelitian Survei. (Jakarta: LP3ES).

Mosnan, M. (2014). Pendekatan Saintifik dan Kontekstual dalam Pembelajaran Abad 21. Jakarta: Ghalia Indonesia.

Mulyasa, E. (2014). Pengembangan dan Impelementasi Kurikulum 2013. Bandung: PT Remaja Rosdakarya.

Nazir, Moh. (2011). Metode Penelitian. Jakarta: Ghalia Indonesia.

Riduwan. (2010). Metode dan Teknik Menyusun Proposal Penelitian. Bandung: Alfabeta.

Sani A, Ridwan. (2014). Pembelajaran Saintifik untuk Implementasi Kurikulum 2013. Jakarta: Bumi Aksara.

Sugioyono. (2016). Metode Penelitian Pendidikan Pendekatan Kuantitatif, Kualitatif, dan $R$ $\& D$. Bandung: Alfabeta.

Sundayana, Wachyu. (2014). Pembelajaran Berbasis Tema. Panduan Guru dalam Mengembankan Pembelajaran Terpadu. Jakarta: Erlangga.

Susanto, Ahmad. (2015). Teori Belajar dan Pembelajaran di Sekolah Dasar. Jakarta: Kencana.

Syah, Muhibbin. (2013). Psikologi Belajar. Pengantar Prof. Dr. S.C. Utami Munandar. Jakarta: Rajawali Pers. 